\title{
VARIASI KEMIRINGAN SUDUT TURBULATOR TERHADAP LAJU PERPINDAHAN PANAS PADA ALAT PENUKAR KALOR ALIRAN BERLAWANAN (COUNTER FLOW HEAT EXCHANGER)
}

\author{
Nyoman Aryaa Wigraha \\ JurusanPendidikan Teknik Mesin, Universitas Pendidikan Ganesha \\ Singaraja Indonesia \\ e-mail: arya_wigraha@yahoo.co.id
}

\begin{abstract}
Abstrak
Pengaruh turbulator yang berbentuk Louvered stripsterhadap laju perpindahan panas dan faktor gesekan aliran turbulen pada double tube heat exchanger dapat memecah (partitioning) dan mengganggu (blockage) pola streamline dari fluida yang mengalir kesaluran pipa dalam (inner tube) sehingga mengakumulasi aliran turbulensi dan meningkatkan laju perpindahan kalor dalam pipa. Turbulator Louvered strips memiliki variasi sudut serang $\left(\theta=15^{\circ}, 25^{\circ}, 30^{\circ}\right)$ yang terpasang ditengah-tengah pipa bagian dalam dan searah aliran fluida masuk. Laju aliran fluida (air) panas di bagian pipa dalam diteliti dengan interval 400 It/jam sampai 900 It/jam dan laju aliran air dingin di bagian pipa luar konstan 900 It/jam. Data hasil pengujian dari masing - masing sudut serang turbulator ini dibandingkan data tanpa turbulator (plain tube), secara keseluruhan terjadi peningkatan laju perpindahan kalor sebesar $26 \%$ sampai $58 \%$ dari pada tanpa turbulator serta menghasilkan faktor gesekan dari $25 \%$ sampai $40 \%$. Dengan performance ratio rata -rata tertinggi pada turbulator dengan sudut $30^{\circ}$ sebesar 0,948 .
\end{abstract}

Kata kunci: Turbulator, Heat Exchanger, Counter flow, turbulensi, faktor gesekan, turbulator, efektifitas

\begin{abstract}
Effect of turbulator louvered strips on the rate of heat transfer and friction factor of turbulent flow in a double tube heat exchanger can split and interrupt streamline pattern of the fluid flowing into the pipeline that accumulates the flow of turbulence and increase the rate of displacement heat in the pipeline. Louvered strips have a variation of angle of attack $(\theta=$ $15^{\circ}, 25^{\circ}, 30^{\circ}$ ) which is attached in the middle of the inner pipe and the direction of fluid flow inside. The flow rate of fluid (water) heat in the pipe in the interval studied 400 It / hour to 900 liters / hour and the cold water flow rate in the outer pipe of constant 900 It / hour. Data from each test result of attack is compared to data without turbulator, the overall heat transfer rate increased by $26 \%$ to $58 \%$ of the no turbulator as well as generate friction factor from $25 \%$ to $40 \%$. Performance ratio with the highest average in the turbulator with 300 angle of 0.948 .
\end{abstract}

Key words: louvered strips, Heat Exchanger, Counter flow, turbulence, friction factor, turbulator, effectiveness 


\section{PENDAHULUAN}

Peningkatan efisiensi dari perpindahan energi perlu adanya perubahan parameter - parameter, antara lain perubahan parameter aliran fluida (turbulensi), perubahan area penerimaan energi dan pengkondisian temperatur fluida kerja. Faktor perubahan parameter tersebut sangat penting dalam kontrol suatu proses Engineering baik di Power Plant Industry, Production Processing Utility dll yang akan menentukan kualitas produk yang dihasilkan (Lunsford,1998). Dalam dunia industri pemanfaatan kembali perpindahan energi atau panas sangat diperlukan, dimana perpindahan kalor dapat berlangsung melalui 3 cara, antara lain perpindahan kalor secara molekuler (konduksi), secara aliran (konveksi), secara gelombang elektromagnet (radiasi). Aplikasi perpindahan kalor tersebut banyak ditemui secara rinci dengan penggunaan Heat Exchanger baik berupa kondensor, recuperator, boiler dll. Heat exchanger adalah peralatan yang digunakan untuk memindahkan energi termal (Entalpi) antara dua atau lebih fluida, antara permukaan padat (solid) dan cair/gas, atau antara partikel padat dan partikel cair/gas, pada perbedaan temperatur dan area kontak termal fluida/konveksi paksa, sedangkan roses perpindahan kalor HE ada dua yaitu tipe direct dan indirect (Shah, 2003).

Pengembangan perpindahan kalor dari HE terbagi menjadi beberapa cara yaitu secara cara passive dan active (Lunsford,1998) : Pengembangan HE passive techniq yaitu merekayasa aliran fluida kerja melalui penambahan area permukaan perpindahan panas (turbulator) pada pipa - pipa HE seperti pengasaran permukaan dinding dalam/luar pipa, alat pemusar aliran/swirler/penghalang, external atau internal fin, dll. Sedangkan secara active technique yaitu dengan memberikan penambahan energy ke fluida kerja seperti pemberian getaran secara mekanik ke area fluida kerja agar dapat memecah lapisan batas kalor. Pengembangan perpindahan kalor dari Heat exchanger dimaksudkan untuk mengatasi permasalahan permasalahan seperti laju perpindahan kalor, area pemukaan perpindahan kalor, faktor gesekan, pola aliran fluida kerja, daya pompa, jenis Heat Exchanger yang digunakan, serta jenis material $\mathrm{HE}$ (Bergles, 1998). Dalam penelitian ini akan mengembangkan teknik passive yaitu dengan memodifikasi dan menggabung kanti peturbulator insert HE Louverd strips Insert (Smith Eiamsa-ard;2007) dan Twisted tape Insert atau disebut "Louvered Strips Inserts" yang memiliki variasi sudut serang sirip $\theta=15^{\circ}, 25^{\circ}$ dan $30^{\circ}$. Pemasangan turbulator dapat memecah (partitioning) dan mengganggu (blockage) pola streamline dari fluida yang mengalir ke saluran pipa dalam (inner tube). Dengan kata lain akan mengalirkan aliran fluida sesuai dengan arah vector pergerakkan fluida sesuai dengan bentuk dan model turbulator. Akibatnya lintasan dan luasan bebas alir flui di dalam pipa berkurang sehingga akan meningkatkan kecepatan alir fluida. Kecepatan pada fluida ini akan meningkatkan kontak termal antara permukaan pipa dalam dengan fluida yang mengalir. Hal ini merupakan adanya rotasi (curl) fluida yang bersinggungan dengan penghalang turbulator dimana ada perbedaan tekanan local sehingga mengakibatkan olakan - olakan aliran berpusar fluida (swirl) diantara ruang antar sirip (fin) turbulator (Saunders, 1986). Fluida yang berpusar ini akan memperbesar gradient temperature artinya ada pelepasan 
kalor yang besar ke sekitarnya akibat meningkatkan pergerakan partikel fluida (turbulensi) untuk mentransferkan energinya keluar atau memiliki koefisien mampu pindah kalor yang tinggi (high heat transfer coefficient). Pemasangan turbulator juga menerapkan konveksi paksa, hal ini berkaitan dengan besarnya energy diterima kedalam fluida maupun perpindahan kalor antar pipa dan fluida.

\section{METODE}

Dalam penelitian ini menggunakan double tube heat exchanger, dengan pipa bagian luar dari stainles steel berdiameter dalam $76,2 \mathrm{~mm}$ dengan dan pipa bagian dalam dari tembaga bediameter 25,4 $\mathrm{mm}$ dengan panjang 1,1 meter. Fluida yang digunakan adalah air baik pada pipa bagian luar (shell) dan pipa bagian dalam (tube) sedangkan arah aliran dalam heat exchanger ini yaitu counter flow. Untuk kerugian pipa dan kerugian panas ke lingkungan diabaikan karena sistem dianggap steady. Pengukuran pressure drop pada pipa bagian dalam

menggunakan manometer. Air dingin mengalir konstan pada pipa luar (shell) 900 It/jam dan temperaturnya dijaga konstan $27^{\circ} \mathrm{C}$. Sedangkan pada air panas mengalir pada pipa dalam (tube) bervariasi dari 400 It/jam sampai 900 It/jam dengan kenaikan interval 100 It/jam dan temperatur reservoirnya konstan $65^{\circ} \mathrm{C}$ dengan toleransi temperatur $\pm 0,1^{\circ} \mathrm{C}$. Untuk menjaga temperatur air panas maka digunakan daya heater $2400 \mathrm{KW}$ serta menggunakan automatic thermocontroler sedangkan untuk menjaga temperatur reservoir dingin maka digunakan sirkulasi dengan air PDAM.Louvered strips insert ini berjumlah 22 buah dan terbuat dari stainless steel dengan variasi sudut serang $\theta=15^{\circ}, 25^{\circ}, 30^{\circ}$. Ukuran dan bentuk turbulator ini seperti pada gambar 2 .

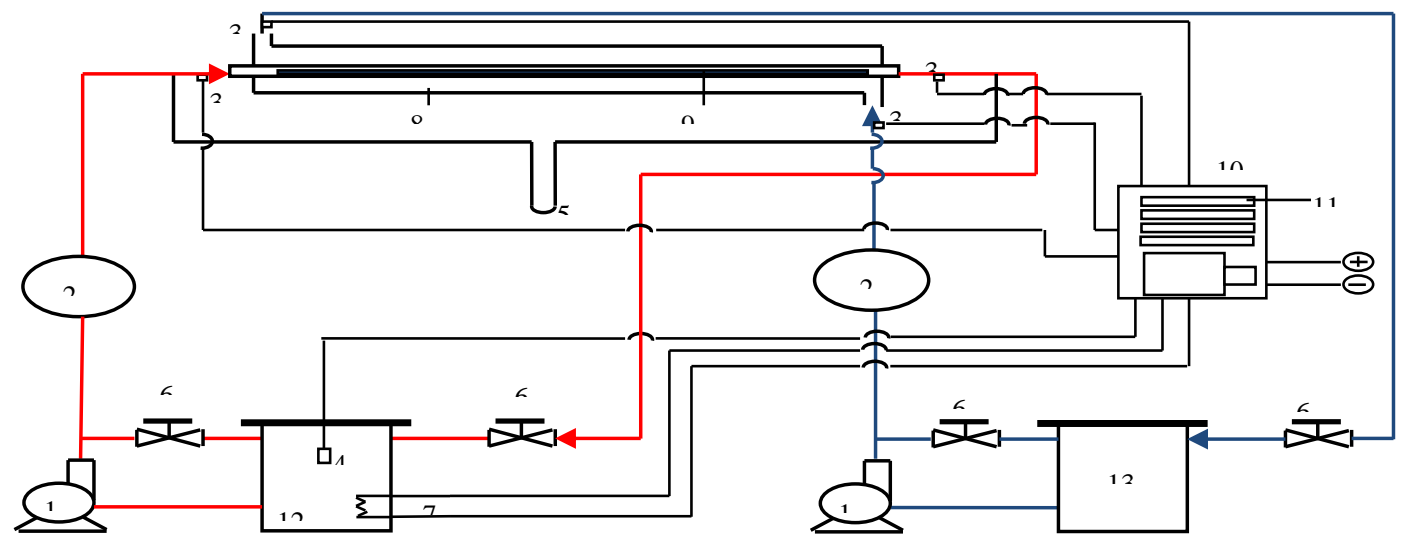

Gambar 1. Skema peralatan penelitian:1 pompa air 1/4 PK, 2 Debit meter, 3 LM 35, 4 Thermocouple tipe K, 5 Manometer, 6 Ball Valve, 7 Heater, 8 Double tube HE, 9 Louvered strip twisted insert, 10 control panel, 11 Display digital, 12 \& 13 Reservoir air panas dan dingin. 

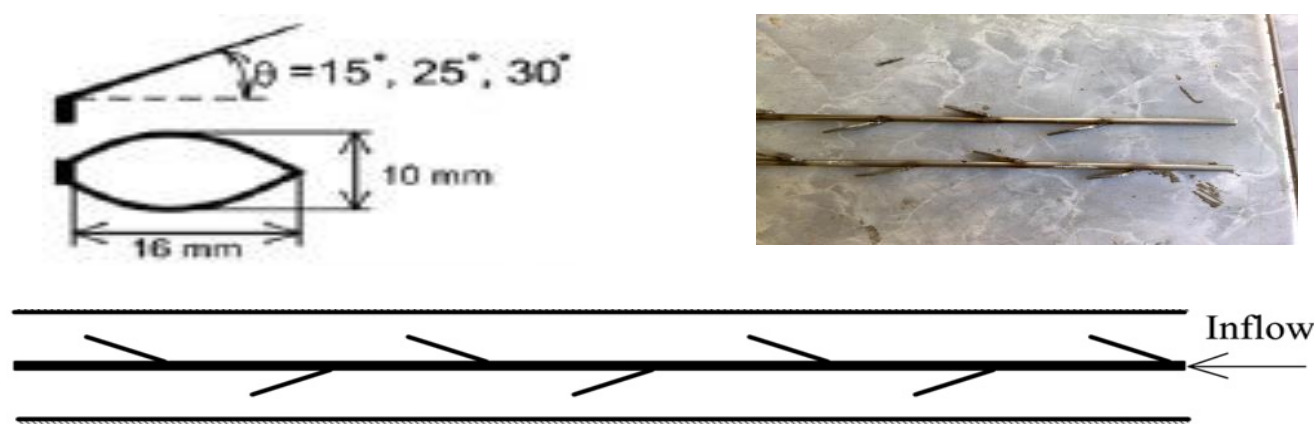

Gambar 2. Ukuran dan bentuk turbulator

Dalam penelitian ini air dimasukkan ke reservoir air panas dan air dingin. Kemudian dilakukan kalibrasi pada debit meter untuk air dingin sebesar 900 It/jam dan debit meter air panas dari 400 It/jam 900 It/jam dimana kalibrasi ini dilakukan tiap kenaikan interval 100 It/jam. Air pada reservoir panas dipanaskan dengan heater sampai suhunya $65^{\circ} \mathrm{C}$, setelah itu pompa air panas dinyalakan untuk mengalirkan air kedalam pipa dalam (tube) sampai kondisi steady pada temperatur Thin $\left(65^{\circ} \mathrm{C}\right)$ dan Thout yang terbaca pada display digital serta steady perbedaan ketinggian yang terukur pada manometer. Dan selanjutnya reservoir air dingin yang berkondisi steady pada suhu $27^{\circ} \mathrm{C}$ (Tcin) dialirkan ke dalam pipa luar (shell) melalui pompa air dingin. Setelah itu dilakukan pencatatan dan pengambilan data 5 kali dengan pengulangan 3 kali dari temperatur Thin, Thout, Tcin,Tcout dan $\Delta \mathbf{z}$ (perbedaan ketinggian $\mathrm{cmH}_{2} \mathrm{O}$ ). Prosedur penelitian ini dilakukan pada plain tube dan Heat exchnager dengan turbulator Louvered strips insert.

Perubahan temperatur Thin, Thout, Tcin,Tcout berpengaruh terhadap propertis fluida antara lain $\operatorname{Pr}, \rho, c p, v, k, \mu$ yang didapatkan tabelmelaluiberdasarkantemperatur rata - rata fluida dingin dan fluida panas (temperaturbulk),

$$
\begin{aligned}
T_{\text {bulk hot }}= & \left(T_{\text {hin }}+T_{\text {hout }}\right) / 2 \text { dan } T_{\text {bulk cold }}= \\
& \left(T_{\text {cin }}+T_{\text {cout }}\right) / 2
\end{aligned}
$$

Karena aliran fluida pada doublé tuve heat exchanger ini cross flow maka;

$\Delta T_{L M T D}=\frac{\Delta T_{1}-\Delta T_{2}}{\ln \left(\Delta T_{1} / \Delta T_{2}\right)} \quad$ dengan

$$
\begin{aligned}
\Delta T_{1} & =T_{h, \text { in }}-T_{c, \text { out }} \\
\Delta T_{2} & =T_{h, \text { out }}-T_{c, \text { in }}
\end{aligned}
$$

Luasan permukaan total perpindahan kalor As ;

As = Luasan permukaan pipa dalam + Luas total turbulator

Dimana luas total sirip ini dipengaruhi sudut sinus dari louvered strip twisted insert $\theta=15^{\circ}, 25^{\circ}$ dan $30^{\circ}$.KoefisienperpindahankalorU;

$$
U=\frac{1}{\frac{1}{h_{i} A_{i}}+\frac{\ln \left(D_{o} / D_{i}\right)}{2 \pi k L}+\frac{1}{h_{o} A_{o}}}
$$

Dimana $A_{i}$ dan $A_{o}$ adalah luasan total permukaan perpindahan kalor pipa dalam bagian dalam

$$
A_{o}=\pi D_{o} L \text { dan } A_{i}=\pi D_{i} L
$$

dengan koefisien konveksi ;

Jurnal Sains dan Teknologi|658 


$$
h_{\text {in,out }}=\frac{k_{\text {in,out }}}{D_{h}} N u_{\text {in }, \text { out }}
$$

Untuk perhitungan angka Nusselt dari pipa luar dan pipa dalam pada double tube heat exchanger ini dengan menggunakan persamaan Dittus-Boilter:

$$
\begin{aligned}
N u_{o} & =\frac{h_{o} \cdot D_{h}}{k}=0.023 \operatorname{Re}_{o}^{0.8} \operatorname{Pr}_{o}^{0.33} \text { dan } \\
N u_{i} & =\frac{h_{i} \cdot D_{h}}{k}=0.023 \operatorname{Re}_{i}^{0.8} \operatorname{Pr}_{i}^{0.4}
\end{aligned}
$$

Dimana $D_{h}=D_{0}-D_{i}$ adalah diameter hidrolik yang dipengaruhi luasan aliran fluida (perimeter basah) didalam pipa - pipa Heat exchanger. Dan angka Reynold berdasarkan ;

$$
\operatorname{Re}_{\text {in,out }}=\frac{u \cdot D}{v}=\frac{\rho_{\text {in }, \text { out }} \cdot u_{\text {in,out }} \cdot D_{\text {im }, \text { out }}}{\mu_{\text {in out }}}
$$

Maka laju perpindahan kalor double tube heat exchanger ;

$$
Q=U A_{s} \Delta T_{L M T D}
$$

Sedangkan capacity ratio (c) dan Number of Transfer Unit :

$$
c=\frac{C_{\min }}{C_{\max }} \text { dan } \quad N T U=\frac{U A_{s}}{C_{\min }}=\frac{U A_{s}}{\left(\dot{m} C_{p}\right)_{\min }}
$$

Hubungan antara NTU dan capacity
ratio
(c) terhadap
( $)$ pada

counter flow heat exchanger, sebagai berikut :

$$
\begin{gathered}
\varepsilon=\frac{1-\exp [-N T U(1-c)]}{1-c \exp [-N T U(1-c)]} \\
f=\frac{\Delta P}{\left(\frac{L}{D}\right)\left(\rho \frac{u^{2}}{2}\right)}
\end{gathered}
$$

Sedangkan faktor gesekan didalam pipa untuk aliran turbulen dipengaruhi besarnya penurunan tekanan $(\Delta P)$ sebagai akibat adanya hambatan dari pemasangan turbulator louvered strip kedalam pipa heat exchanger. Artinya dengan semakin besar penurunan tekanan maka faktor gesekan akan bertambah besar, sehingga kerja pompa akan meningkat ;

\section{HASIL DAN PEMBAHASAN}

Dari gambar 1 dapat dilihat dengan adanya pemasangan berbagai variasi sudut louvered strips, maka akan semakin besar sudut louvered strips maka akan semakin besar faktor gesekan. Faktor gesekan akan semakin menurun dengan kenaikan debit dikarenakan hambatan pada fluida panas semakin besar dengan kecepatan fluida semakin besar, meskipun penurunan tekanan semakin besar.

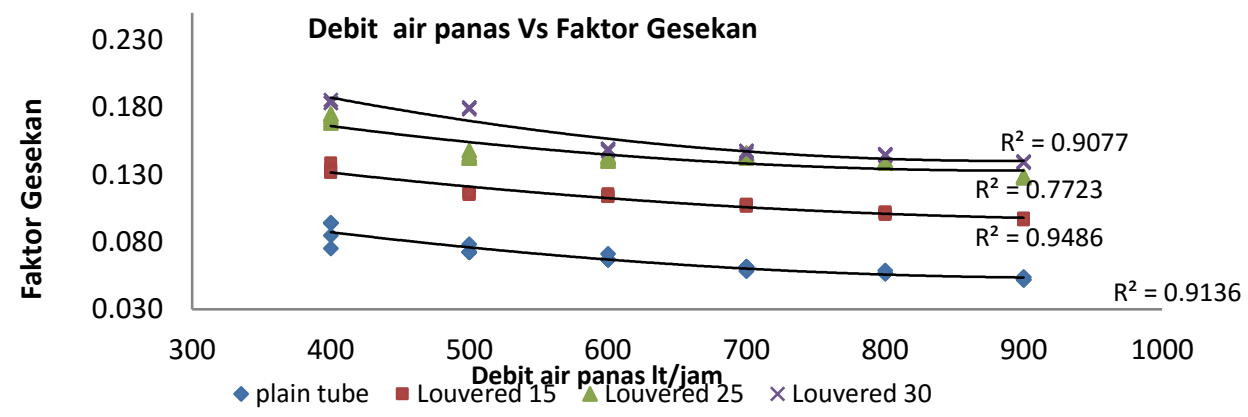

Gambar 3. Grafik pengaruh berbagai variasi sudut louvered strips terhadap faktor gesekan pada berbagai variasi debit air panas 


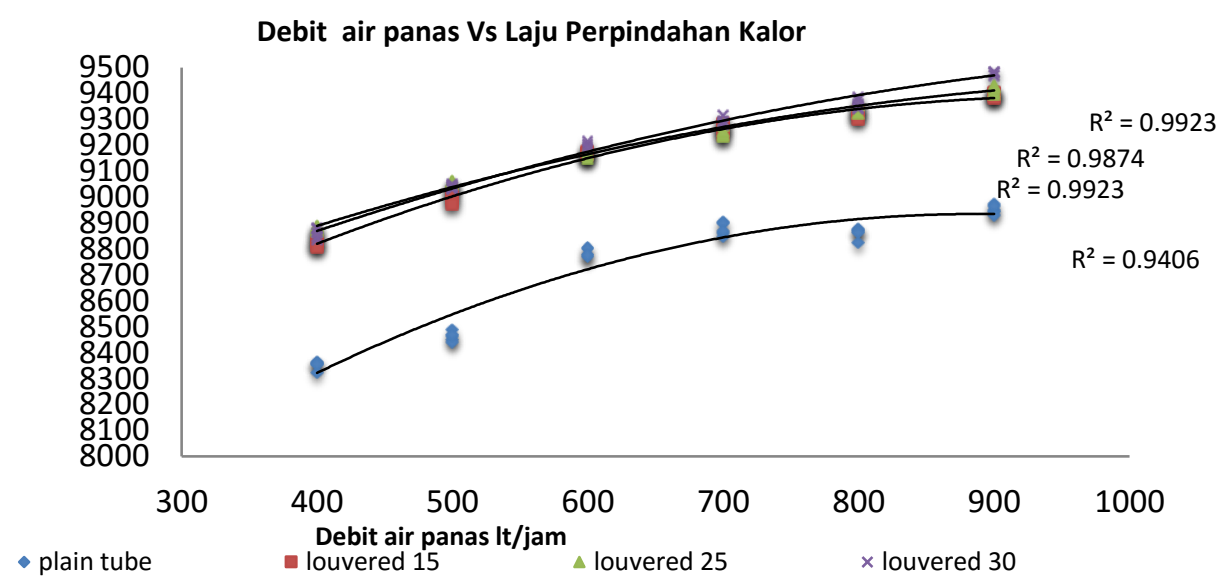

Gambar 4. Grafik pengaruhberbagai variasi sudut louvered strips terhadap laju perpindahan kalor yang ditimbulkan pada berbagai variasi debit

Pada gambar 4 menunjukkan bahwa dengan adanya pemasangan penghalang dengan variasi sudut louvered strips menyebabkan terjadinya peningkatan laju perpindahan kalor dibandingkan dengan tanpa penghalang, sebanding dengan peningkatan debit air panas, disebabkan semakin besar sudut dari louvered strips akan mempersempit penampang sehingga meningkatkan kecepatan rata-rata dari fluida dan akan semakin tinggi laju perpindahan kalornya.

Pada gambar 5 ditunjukkan grafik perbandingan angka Reynold pada plain

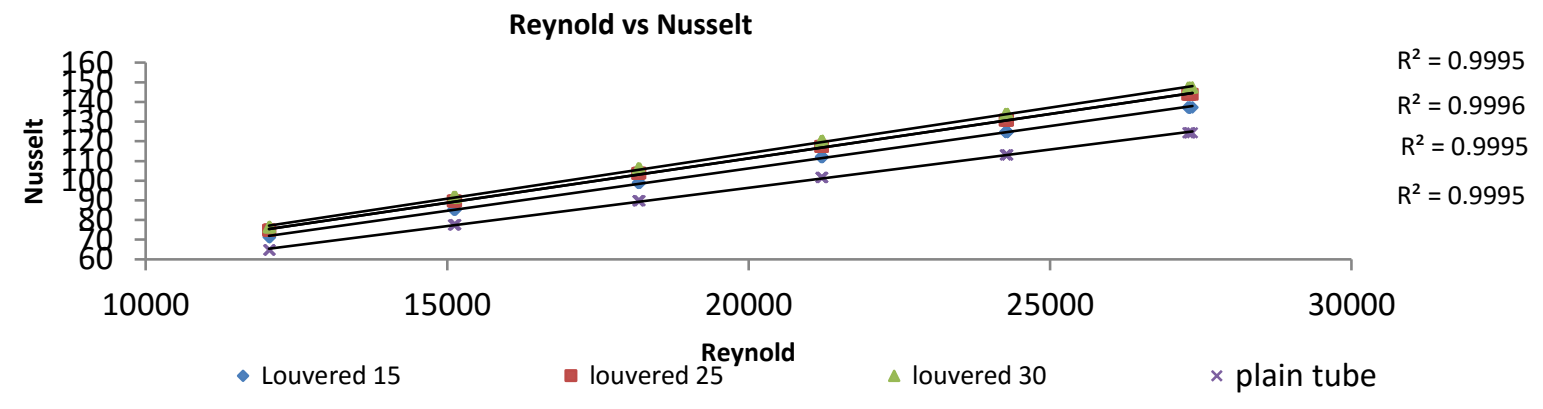

Gambar 5. Grafik perbandingan angka Nusselt dari berbagai variasi sudut louvered strips tube dengan angka Nusselt pada berbagai variasi sudut louvered strips. Dapat dilihat adanya kenaikan angka Nusselt dari penghalang dengan berbagai variasi sudut louvered strips dibandingkan dengan tanpa penghalang, yang mana semakin besar angka Nusselt, maka perpindahan kalor konveksi akan semakin efektif, dimana angka Nusselt menunjukkan besar perpindahan kalor konveksi terhadap besar perpindahan kalor konduksi pada lapisan fluida yang sama.

\section{dengan denganangka Reynold}




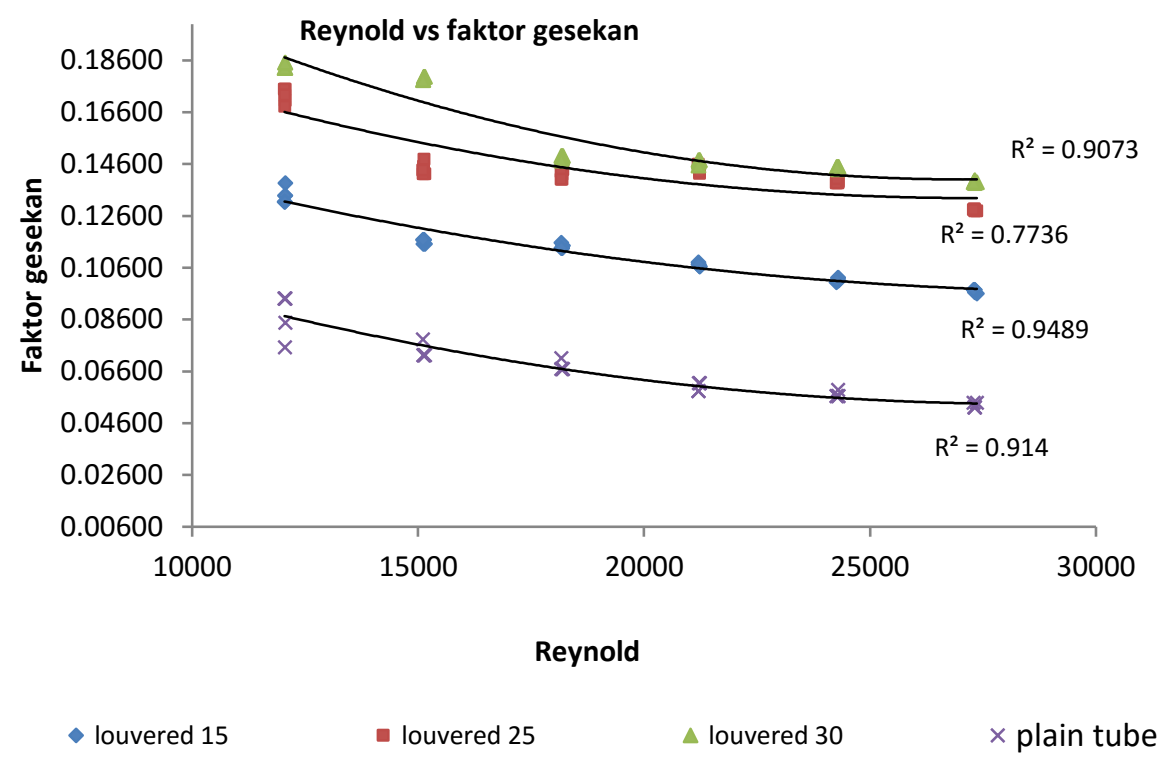

Gambar 6. Grafik perbandingan angka Reynold dengan faktor gesekan berbagai variasi sudut louvered strips

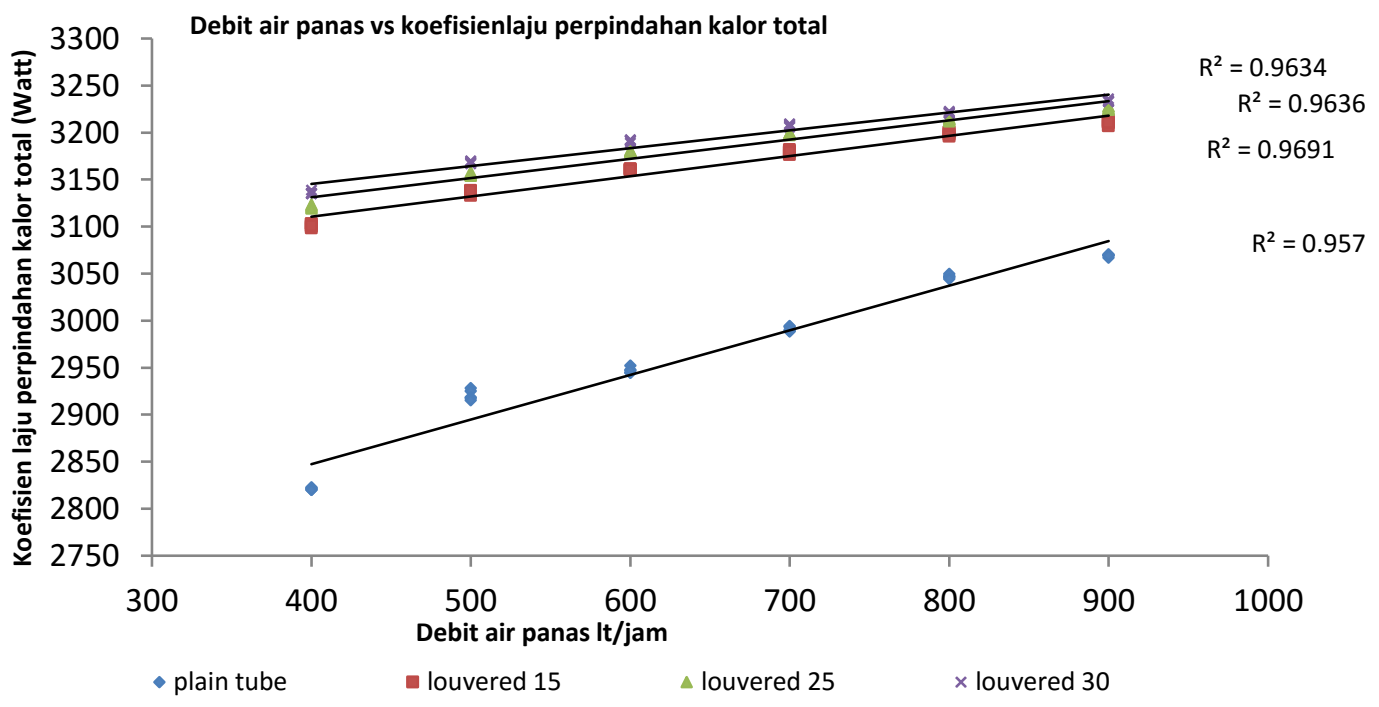

Gambar 7. Grafik perbandingan debit air panas dengan koefisien laju perpindahan kalor total pada berbagai sudut louvered strips

Pada gambar 6 dapat dilihat dengan kenaikan angka Reynold diikuti dengan penurunan faktor gesekan, penurunan faktor gesekan akan meningkatkan gaya 
inersia yang menimbulkan fluktuasi fluida yang cepat dan acak yang akan meningkatkan turbulensiyang akan menaikkan bilangan Reynold.

Pada gambar 7 dapat dilihat pada debit air panas yang sama didapatkan peningkatan terhadap koefisien perpindahan kalor menyeluruh pada masing-masing pengujian dengan variasi sudut louvered strips, peningkatan terhadap koefisien perpindahan kalor menyeluruh dapat menunjukkan bahwa proses perpindahan kalor melalui mekanisme perpindahan kalor konveksi pada pipa dalam akan semakin efektif seiring dengan adanya peningkatan sudut louvered strips sehingga hambatan thermal konveksi pada aliran fluida panas juga semakin kecil.

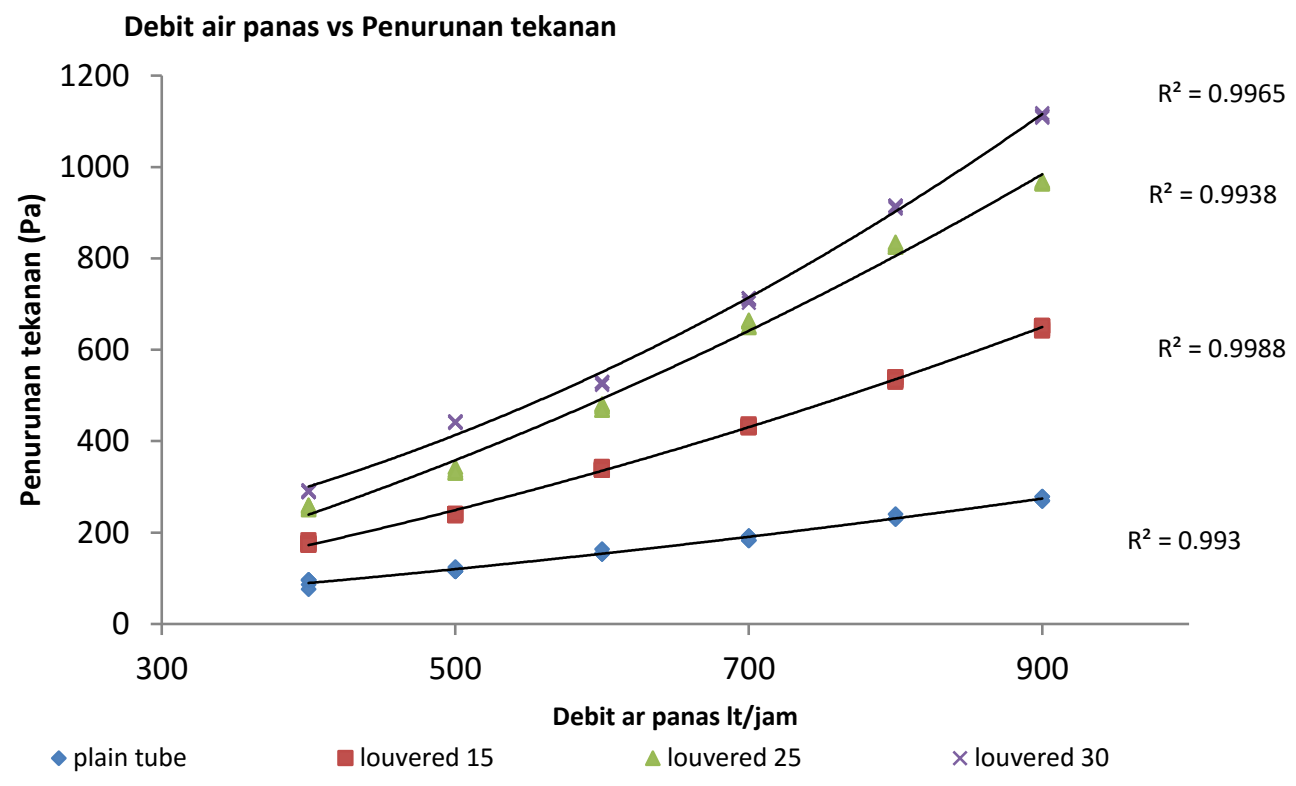

Gambar 8. Hubungan antara variasi debit air panas dengan terhadap penurunan tekanan pada tiap-tiap variasi sudut louvered strips

Pada Gambar 8 dapat dilihat semakin meningkatnya sudut louvered strips akan meningkatkan faktor kerugian komponen pada aliran air panas. Pemasangan louvered strip menyebabkan luas penampang aliran air panas menjadi lebih kecil, akibatnya aliran air akan mempunyai kecepatan yang lebih untuk mempertahankan debit aliran air panas pada debit yang sama, sehingga gesekan dengan dinding pipa dalam maupun dengan louvered strips juga akan semakin meningkat, sehingga penurunan tekanan juga akan semakin meningkat.

Pada Gambar 9 dapat dilihat dengan semakin meningkatnya debit aliran pada masing-masing pengujian dengan maupun tanpa pemasangan louvered, efektifitas cenderung meningkat, hal ini disebabkan dengan adanya peningkatan

Jurnal Sains dan Teknologi|662 
debit maka gerakan fluida akan semakin cepat menggantikan fluida panas yang lebih rendah suhunya di sekitar permukaan dinding pipa dalam dengan partikel fluida panas yang lain, temperatur keluar fluida menjadi lebih panas dibandingkan dengan aliran fluida pada debit yang lebih rendah.

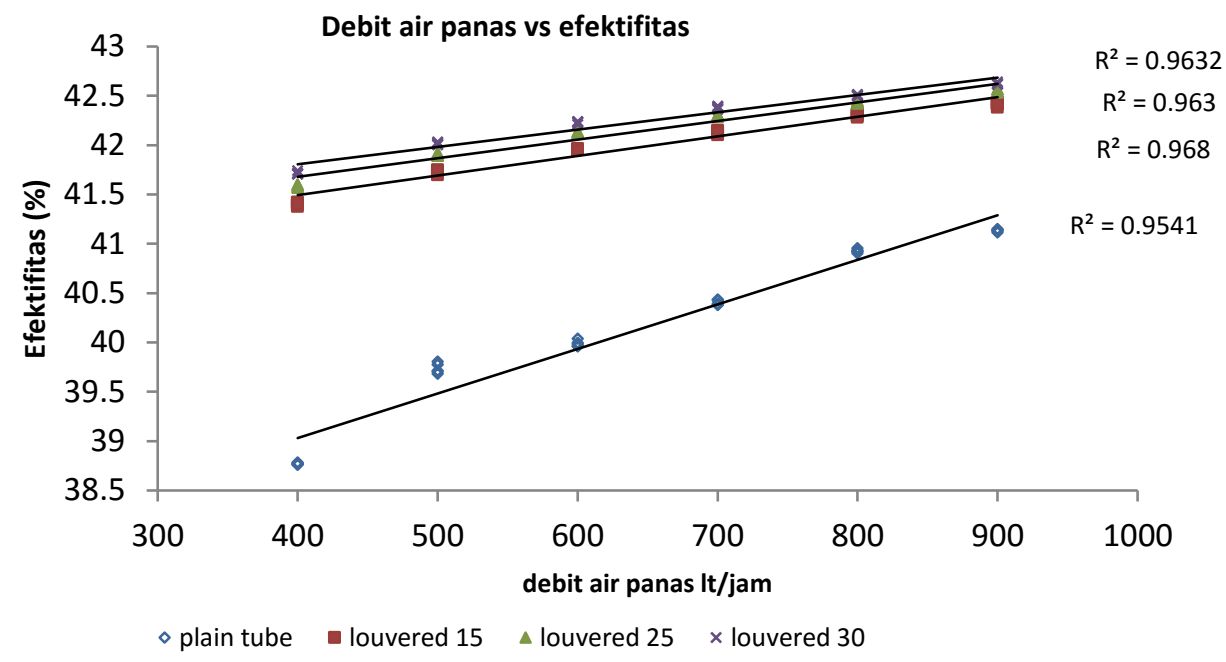

Gambar 9. Grafik pengaruh debit air panas terhadap efektifitas pada tiap-tiap variasi sudut louvered strips

Daya pompa mengatasi kerugian penurunan tekanan vs laju perpindahan kalor

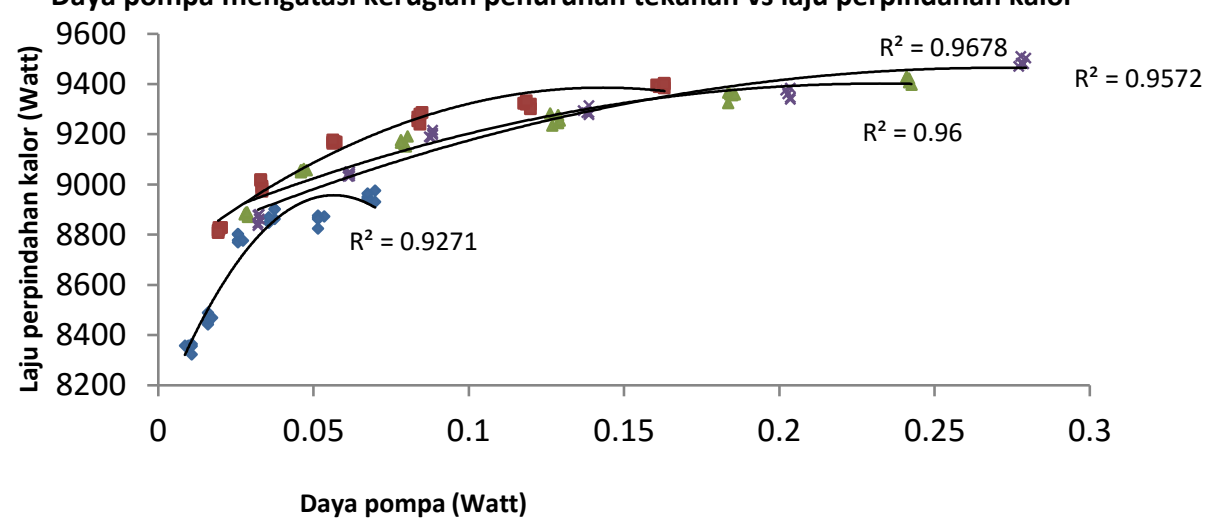

Gambar 10. Grafik perbandingan daya pompa untuk mengatasi kerugian penurunan tekanan dengan laju perpindahan kalor pada berbagai variasi sudut louvered strips

Pada Gambar 10 menunjukkan grafik perbandingan daya pompa yang digunakan untuk mengatasi kerugian penurunan tekanan dengan laju perpindahan kalor pada berbagai variasi sudut louvered strips pada daya pompa yang sama, dengan semakin naiknya laju perpindahan kalor maka akan semakin 
meningkat daya pompa yang dibutuhkan untuk mengatasi kerugian penurunan tekanan.

\section{PENUTUP}

Dari penelitian pengaruh louvered strips terhadap laju perpindahan panas dan faktor gesekan dapat disimpulkan bahwa semakin besar sudut louvered strips dengan bertambahnya debit air panas pada masing-masing pengujian dengan variasi debit air panas yang sama akan meningkatkan laju perpindahan kalor, menurunkan tekanan, dan meningkatkan efektifitas. Kesimpulan lain yang didapatkan adalah faktor gesekan akan semakin menurun dengan meningkatnya debit air panas pada berbagai variasi sudut louvered strips, dikarenakan hambatan pada fluida panas semakin besar dengan kecepatan fluida semakin besar, meskipun penurunan tekanan semakin besar

\section{DAFTAR PUSTAKA}

Bergles, A.E. 1998. The imperative to enhance heat transfer, in :Energy conservation through heat transfer enhancement of heat exchangers. NATO Advanced Study Institute. Izmir - Turkey.

Byron Black of the Brown Fintube Company. Heat transfer innovators.URL

http://www.kochheattransfer.com/cp/u serfile_Byron_black_of_the_brown_fi ntube_company.pdf.16 februari 2010.

Eiamsa-ard, Smith.\&Promvonge, P. 2006. Heat transfer characteristics in a tube fitted with helical screw-tape with/without core-rod inserts. Bangkok: King Mongkuts Institute of Technology Ladkrabang.
Eiamsa-ard, Smith.Pethkool, Somsak. Thianpong, Chinaruk. \&Promvonge, P. 2007 Turbulent Flow Heat Transfer and Pressure Loss in a Double Pipe Heat Exchanger with Louvered Strip Inserts. Bangkok: King Mongkuts Institute of Technology Ladkrabang.

Engineering data book III 5-1. Wolverine Tube Heat Transfer Data book. Wolverine Tube, Inc. URL :http://www.wlv.com/products/databoo k/ch2_2.pdf. 16 februari 2010.

Introduction to engineering heat transfer. URL

http://www.ocw.mit.edu/../10_part1_3. pdf.16 Februari 2010.

Lunsford, Kevin M. 1998. Increasing heat exchanger performance.Bryan : Texas US. Bryan Research \& Engineering, Inc.

Pethkool, Somsak. Eiamsa-ard, Smith.Ridluan, Artit. And Promvonge, P. 2006 Effect of Louvered Strips on Heat Transfer in a Concentric Pipe Heat

Excahanger.Bangkok:KingMongkuts Institute of Technology Ladkrabang.

Saunders, E.A.D. 1986. Heat Exchangers Selection, Design and Construction.Darlington :Whessoe Heavy Engineering Ltd.

Shah, Ramesh K. \&Sekulic, Dušan P. 2003. Fundamentals of Heat Exchan 